Удк 636.5 .03

DOI: $10.36461 / N P .2019 .52 .3 .016$

\title{
ЦИТОМЕТРИЧЕСКИЕ ПОКАЗАТЕЛИ ЭПИТЕЛИАЛЬНОГО СЛОЯ ЯЙЦЕВОДА КУР В ВОЗРАСТНОМ ИНТЕРВАЛЕ 30-120 СУТОК
}

\author{
Р. Ю. Хохлов, доктор биол. наук, доцент; С. И. Кузнецов, канд. биол. наук, дочент
}

Федеральное государственное бюджетное образовательное учреждение высшего образования Пензенский ГАУ, Россия, т. (8412) 628-151, e-mail: roman_kh@rambler.ru

Статья посвящена изучению цитометрических показателей эпителиального слоя слизистой оболочки яйцевода кур до начала яйцекладки, а именно с 30- по 120-суточный возраст. В результате анализа полученных цитометрических показателей установлено, что толщина эпителиального слоя краниального отдела яйцевода поступательно увеличивается от 30до 90-суточного возраста. В каудальной части яйцевода аналогичная тенденция прослеживается на месяц позже, то есть с 60-суточного возраста. Наибольшие ядра эпителиоциты краниального отдела имели в 90-суточном возрасте, а в каудальном в 120-суточном возрасте. Размеры эпителиальных клеток в краниальном отделе менялись от минимальных значений в 30-суточном возрасте до максимальных в 60-суточном возрасте. В каудальном отделе минимальная площадь клеток эпителия отмечается, равно как и в краниальном, в 30суточном возрасте. Однако, максимальная площадь эпителиоцитов в каудальном отделе не совпадает с краниальным отделом, так как наиболее крупные эпителиальные клетки в каудальном отделе отмечаются в 120-суточном возрасте. Минимальное отношение ядер к цитоплазме в краниальной части яйцевода отмечалось в 60-суточном возрасте, а в каудальной в 90-суточном возрасте. Наибольшее ядерно-цитоплазматическое отношение в краниальной части зафиксировано в 30-суточном возрасте, а в каудальной в 30- и 120-суточном возрасте.

Ключевые слова: курица, яйцевод, эпителий, морфогенез, ядерно-цитоплазматическое отношение.

\section{Введение}

Птицеводческая отрасль на протяжении последних лет показывает рост производства яйца и птицы. Так, по данным Федеральной службы государственной статистики Российской Федерации, средняя яйценоскость на одну курицу в 1990 году составляла 236 штук, а за последние пять лет, с 2014 года по 2018 год, этот показатель в среднем находился на уровне 308 штук [18]. Безусловно, уровень яичной продуктивности определяется многочисленными факторами, одни из которых оказывают большее, другие меньшее влияние на яйценоскость кур-несушек. Однако, все они требуют пристального внимания птицеводов. Одним из таких факторов является морфоффункциональное состояние репродуктивной системы птицы. Яичник и яйцевод птиц являются очень чувствительными органами к различного рода отклонениям от принятой технологии выращивания птицы. Поэтому актуальным направлением ветеринарной морфологии является изучение функциональной морфологии органов размножения сельскохозяйственной птицы, определение этапов и критических периодов развития яичника и яйцевода. Вопросам морфогенеза репро- дуктивных органов птиц уделено значительное внимание в отечественной научной литературе, причем большинство исследований проведено на курах [1, 4-10, $13,14]$. Вместе с тем, имеются данные по морфологии репродуктивной системы гусей [2, 3, 12,], уток [11]. Не остаются без внимания подобные вопросы и в научном сообществе за рубежом [15-17].

Bce вышеперечисленные аспекты определяют востребованность научных исследований, направленных на более многогранное изучение функциональной морфологии органов размножения продуктивной птицы.

Целью настоящего исследования являлось изучение цитотометрических показателей эпителиального слоя яйцевода кур в возрастном интервале 30-120 суток.

\section{Методы и материалы}

Материалом для исследования служили куры-несушки кросса «Ломан Браун» 30-, 60-, 90-, 120-суточного возраста. Анатомиический уровень исследования включал препарирование и визуальную оценку яйцевода. Для гистологического исследования брали кусочки яйцевода из краниальной и каудальной частей яйцевода. Фиксировали в $8 \%$ нейтральном формалине. 
Приготавливали гистологические срезы толщиной 8 мкм, которые окрашивали гематоксилином и эозином. Цитометрию препаратов осуществляли на микроскопе Micros с помощью компьютерной программы ScreenMeter 1.0. При определении математических параметров показателей рассчитывали среднюю арифметическую $\mathrm{M}$, её ошибку $\mathrm{M}_{\mathrm{m}}$. Статистическую обработку цифрового материала проводили с помощью программы Microsoft Excel.

\section{Результаты}

Толщина эпителия слизистой оболочки краниального отдела в 30-суточном возрасте составила $9,17 \pm 0,52$ мкм $\left(\mathrm{C}_{\mathrm{v}}=\right.$ $17,12 \%)$. Площадь ядер эпителиоцитов краниального отдела яйцевода составила $12,53 \pm 0,92$ мкм $^{2}\left(C_{v}=22,03 \%\right)$. Площадь эпителиальных клеток составила 22,11 \pm 1,87 мкм $^{2}\left(\mathrm{C}_{\mathrm{v}}=25,43\right.$ \%). Ядерно-цитоплазматическое отношение (ЯЦО) эпителиоцитов краниального отдела составило 1,39 \pm $0,12\left(\mathrm{C}_{\mathrm{v}}=25,95 \%\right)$.

Что касается каудального отдела яйцевода 30-суточных цыплят, то следует отметить, что толщина эпителиального слоя зафиксирована на уровне $6,27 \pm 0,34$ мкм ( $\mathrm{C}_{\mathrm{v}}=16,46 \%$ ). Таким образом, в 30суточном возрасте толщина эпителиального пласта краниального отдела в 1,46 раза превышает таковую каудального отдела. Площадь ядер эпителиоцитов каудального

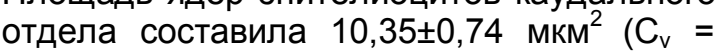
$21,31 \%)$. Сопоставив это значение с площадью ядер краниального отдела, получим, что в краниальном отделе площадь ядер эпителиальных клеток в 1,21 раза больше, чем в каудальной части. Площадь самих эпителиальных клеток каудального отдела 30-суточных цыплят составила $18,63 \pm 1,61$ мкм $\left(C_{v}=25,99 \%\right)$. Таким образом получаем, что площадь эпителиоцитов краниального отдела в 1,19 раза превышает аналогичный показатель каудального отдела. Ядерно-цитоплазматическое отношение составило 1,33 $\pm 0,10\left(C_{v}=22,93 \%\right)$. Таким образом находим, что ядерноцитоплазматическое отношение эпителиоцитов краниального отдела в 1,05 раза больше каудального.

В 60-суточном возрасте в яйцеводе попрежнему выделяют два отдела: краниальный и каудальный. Покровный эпителий краниального отдела однослойный многорядный цилиндрический высотой 9,22 0 ,88 мкм $\left(\mathrm{C}_{\mathrm{v}}=28,59 \%\right)$, что в 1,05 раз больше, чем в 30-суточном возрасте. Площадь ядер эпителиоцитов краниального отдела яйцевода увеличилась, по сравнению с 30суточным возрастом, в 1,07 раза и составила $13,40 \pm 2,61$ мкм $^{2}\left(C_{v}=42,84 \%\right)$, пло-

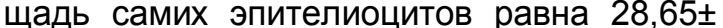
5,09 мкм $^{2}\left(C_{v}=39,04 \%\right)$, что в 1,29 раз больше, чем в 30-суточном возрасте. Ядерно-цитоплазматическое отношение со-

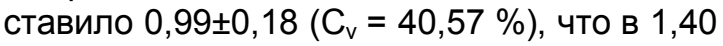
раз меньше, чем в 30-суточном возрасте.

Покровный эпителий каудального отдела яйцевода 60-суточных цыплят уменьшился по сравнению с 30-суточным возрастом в 1,33 раза и составил 4,72 $\pm 0,36$ мкм $\left(\mathrm{C}_{\mathrm{v}}=22,95 \%\right)$. Сопоставляя толщину эпителия краниального и каудального отделов заметим, что в краниальной части этот показатель в 1,95 раза больше, чем в каудальной. Площадь ядер эпителиоцитов каудального отдела увеличилась по сравнению с 30-суточным возрастом в 1,03 раза и составила 10,66 1,16 мкм $^{2}\left(\mathrm{C}_{\mathrm{v}}=23,94 \%\right)$. При сравнении площадей ядер эпителиоцитов краниального и каудального отдела яйцевода отметим, что в краниальном площадь ядер в 1,26 раза больше, чем в каудальном. Площадь эпителиальных клеток каудального отдела 60-суточных цыплят увеличилась по сравнению с таковыми 30-суточных цыплят в 1,06 раза и состави-

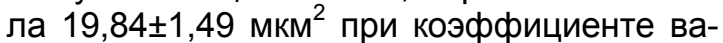
риации 16,56 \%. При сравнении площадей клеток краниального и каудального отделов отметим, что в краниальном площадь клеток в 1,44 раза больше, чем в каудальном. Ядерно-цитоплазматическое отношение эпителиоцитов каудального отдела яйцевода 60-суточных цыплят уменьшилось, по сравнению с предыдущим возрастным интервалом, в 1,08 раза и составило

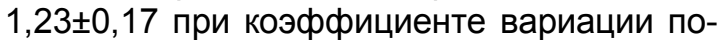
казателя $30,52 \%$.

Стенка яйцевода к 90-суточному возрасту существенно морфологически не изменилась, но, тем не менее, необходимо указать на некоторые особенности. Покровный эпителий краниального отдела, так же как и в 60-суточном возрасте однослойный многорядный цилиндрический высотой $13,07 \pm 0,68$ мкм $\left(C_{v}=15,72 \%\right)$, это в 1,42 раза больше, чем в 60-суточном возрасте. Площадь ядер эпителиальных клеток краниального отдела яйцевода увеличилась по сравнению с предыдущим возрастным интервалом в 1,05 раза и составила $14,03 \pm 1,66$ мкм $^{2}$ (Cv = 25,99\%). Площадь эпителиоцитов уменьшилась по сравнению с 60-суточным возрастом в 1,08 раза и составила $26,55 \pm 3,10$ мкм $^{2}$ при коэфффициенте вариации 25,71\%. Ядерноцитоплазматическое отношение эпителиоцитов краниального отдела 90-суточных цыплят увеличилось по сравнению с 60суточным возрастом в 1,16 раза и составило $1,15 \pm 0,11\left(C_{v}=20,25 \%\right)$. 
Что касается эпителиального пласта каудального отдела яйцевода 90-суточных цыплят, то его толщина по сравнению с 60суточным возрастом увеличилась в 1,17 раза и составила 5,52 $\pm 0,65$ мкм $\left(\mathrm{C}_{\mathrm{v}}=\right.$ $35,10 \%)$. В сравнение с краниальной частью толщина эпителия в каудальной части в 2,37 раза меньше. Площадь ядер эпителиоцитов возрастает, по сравнению с 60суточным возрастом, в 1,28 раза и становится $13,63 \pm 2,09$ мкм $^{2}\left(\mathrm{C}_{\mathrm{v}}=33,84 \%\right)$, что в свою очередь в 1,03 раза меньше аналогичного показателя в краниальной части. Площадь эпителиоцитов каудального отдела яйцевода увеличилась, по сравнению с 60-суточным возрастом, в 1,32 раза и составила 26,12 $\pm 3,46$ мкм $^{2} \quad\left(C_{v}=29,16 \%\right)$. Сопоставляя площадь эпителиоцитов краниального и каудального отделов, следует отметить, что в краниальном она выше в 1,02 раза, чем в каудальном. Ядерноцитоплазматическое отношение эпителиоцитов каудального отдела уменьшилось по сравнению с 60-суточным возрастом в 1,09 раза и составило $1,12 \pm 0,16\left(\mathrm{C}_{\mathrm{v}}=31,15 \%\right)$. При сравнении ЯЦО эпителиоцитов краниального и каудального отделов яйцеводов 90-суточных цыплят отметим, что в каудальном этот показатель в 1,03 раза выше, чем в краниальном.

Толщина покровного эпителиального слоя краниального отдела яйцевода увеличилась к 120-суточному возрасту кур в 1,25 раза и составила $16,35 \pm 0,93$ мкм $\left(\mathrm{C}_{\mathrm{v}}=\right.$ $17,15 \%$ ). В каудальной части яйцевода 120-суточных цыплят так же произошло увеличение показателя толщины покровного эпителия по сравнению с 90-суточным возрастом в 1,79 раза и она составила

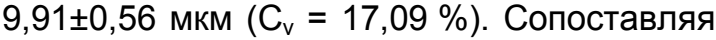
толщину эпителия двух отделов отметим, что в краниальном отделе этот показатель в 1,65 раза больше, чем в каудальном.

Площадь ядер эпителиоцитов краниальной части яйцевода 120-суточных кур уменьшилась, по сравнению с 90-суточным возрастом, в 1,07 раза и составила $13,09 \pm$ 1,29 мкм $^{2}\left(C_{v}=21,79 \%\right)$. Площадь самих эпителиоцитов так же уменьшилась за аналогичный период в 1,04 раза до значения 25,58 $\pm 2,29$ мкм $^{2}\left(C_{v}=19,77 \%\right)$. Ядерно-цитоплазматическое отношение снизилось по сравнению с 90-суточным возрастом, в 1,07 раза и составило $1,07 \pm 0,09$ $\left(C_{v}=20,56 \%\right)$.

Что касается каудального отдела яйцевода, то в нем цитометрические показатели изменялись в противоположном направлении, по сравнению с краниальным отделом, а именно в сторону увеличения. Рассмотрим эти изменения подробней.
Площадь ядра эпителиальных клеток слизистой оболочки яйцевода каудального отдела увеличилась, по сравнению с 90суточным возрастом, в 1,13 раза и соста-

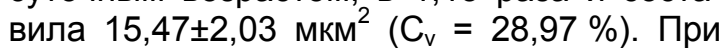
сравнении площадей ядер эпителиоцитов краниального и каудального отделов отметим, что в каудальном этот показатель в 1,18 раза больше, чем в краниальном.

Площадь эпителиальных клеток, как и ядер так же увеличилась по сравнению с 90-суточным возрастом в 1,04 раза и со-

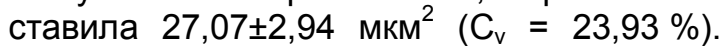
Если сопоставить площадь эпителиоцитов краниального и каудального отделов яйцевода, то заметим, что в каудальном она в 1,06 раза выше, чем в краниальном.

Ядерно-цитоплазматическое отношение эпителиоцитов каудального отдела яйцевода 120-суточных кур увеличилось по сравнению с таковым 90-суточных в 1,19 раза и составило $1,34 \pm 0,13\left(\mathrm{C}_{\mathrm{v}}=21,75 \%\right)$. При сопоставлении ЯЦО краниального и каудального отделов отметим, что в каудальном это отношение в 1,25 раза больше, чем в краниальном.

\section{Заключение}

Таким образом, толщина эпителиального слоя краниального отдела яйцевода поступательно увеличивается от 30- до 90суточного возраста с 9,17 мкм до 16,35 мкм. В каудальной части яйцевода аналогичная тенденция прослеживается на месяц позже, а именно с 60-суточного возраста. Что касается площади ядер эпителиальных клеток, то наибольшие ядра эпителиоциты краниального отдела имели в 90суточном возрасте, а в каудальном в 120суточном возрасте.

Размеры эпителиальных клеток в краниальном отделе менялись от минимальных значений в 30-суточном возрасте (22,11 мкм) до максимальных в 60суточном возрасте (26,55 мкм). В каудальном отделе минимальная площадь клеток эпителия отмечается, равно как и в краниальном, в 30-суточном возрасте. Однако, максимальная площадь эпителиоцитов в каудальном отделе не совпадает с краниальным отделом, так как наиболее крупные эпителиальные клетки в каудальном отделе отмечаются в 120-суточном возрасте.

Минимальное отношение ядер к цитоплазме в краниальной части яйцевода отмечалось в 60-суточном возрасте, а в каудальной в 90-суточном возрасте. Наибольшее ядерно-цитоплазматическое отношение в краниальной части зафиксировано в 30-суточном возрасте, а в каудальной в 30- и 120-суточном возрасте. 


\section{Лuтература}

1. Александрова, Т. Л. Особенности кровоснабжения репродуктивных органов кур различных пород / Т. Л. Александрова, С. А. Величкевич, Н. Б. Рыбалова // Повышение продуктивности сельскохозяйственных животных: научные труды Ленинградского СХИ. - Ленинград-Пушкин, 1976. C. $100-103$.

2. Бондаренко, Е. Е. Влияние продолжительности отдыха гусей после осенней яйценоскости на продуктивные качества в весенний период / Е. Е. Бондаренко // Птицеводство. - 1985. - Т. 38. - C. 50-54.

3. Бондаренко, Е. Е. Гистоструктура яйцепровода гусей 2-месячного возраста / Е. Е. Бондаренко // Ветеринарная медицина. - 1998. - Вып. 74. - С. 109-114.

4. Волощенко, М.В.Окислительная активность митохондрий белкового отдела яйцевода кур в зависимости от возраста / М. В. Волощенко // Сборник научных трудов. Т. 309. - Харьковский СХИ. - Харьков, 1984. - С. 49-53.

5. Гистофункциональное состояние яйцевода у кур в процессе фрормирования скорлупы / В. И. Георгиевский, К. С. Заблоцкая, Е.В.Федотов, Ю. М. Демин // Известия Тимирязевской сельскохозяйственной академии. - 1988. - Т. 4. - С. 145-150.

6. Гладков, Б. А. Кроветворные ткани в яичнике кур / Б. А. Гладков // Материалы всероссийской научной и учебно-методической конференции по акушерству, гинекологии и биотехнике размножения животных. - Воронеж, 1994. - С. 43-44.

7. Кушкина, Ю. А. Гистоморфологическая, стереометрическая и гистохимическая характеристика скорлупового отдела яйцевода кур / Ю. А. Кушкина, Р. 3. Сиразиев // Возрастная физиология и патология с.-х. животных: материалы междунар. науч. конф, посвящ. 90-летию проф. В. Р. Филиппова. - Улан-Удэ, 2003. - Ч.1. - С. 42-44.

8. Родин, Е. В. Критические периоды морфогенеза яичника кур в постэмбриональном онтогенезе / Е. В. Родин, С. И. Кузнецов // Актуальные проблемы ветеринарной медицины и биологии: материалы конференции. - Оренбург, 2003. - С. 75-78.

9. Родин, Е. В. Морфология фолликулов яичника кур в препубертатном онтогенезе / Е. В. Родин, С. И. Кузнецов // Актуальные аспекты экологической, сравнительно-видовой, возрастной и экспериментальной морфологии: материалы конференции. - Улан-Уде, 2004. - С. 43-45.

10. Степина, О. Ю. Гистогенез, особенности микроморфологии и гистохимии покровного эпителия различных отделов яйцевода кур в постнатальном периоде онтогенеза / О. Ю. Степина // Достижения эволюции, возрастной и экологической морфологии - практика медицины и ветеринарии: материалы международной научно-практической конференции морфологов. - Омск, 2001. - C. 12-14.

11. Стрижикова, С. В. Морфологические, гистохимические и ультрамикроскопические характеристики покровного эпителия яйцевода утки в период яйцекладки / С. В. Стрижикова // Актуальные проблемы ветеринарной медицины, животноводства, товароведения, обществознания и подготовки кадров на Южном Урале на рубеже веков: материалы конференции. - Троицк, 2000. - Ч.1. - С. $102-104$.

12. Стрижников, В.К. Динамика роста массы тела и органов размножения гусынь в постнатальном онтогенезе / В. К. Стрижников, А. А. Тегза // Актуальные проблемы ветеринарной медицины. - Троицк, 2002. - С. 120-121.

13. Царева, О. Ю. Микроморфология и гистогенез скорлупового отдела яйцевода кур в различные периоды постнатального онтогенеза и в зависимости от фазы полового цикла / О. Ю. Царева // Проблемы ветеринарной медицины, ветеринарно-санитарной экспертизы, биотехнологии и зоотехнии на современном этапе развития агропромышленного комплекса России: сборник материалов Международной научно-практической конференции Института ветеринарной медицины. - Челябинск, 2019. - С. 75-81.

14. Царева, О. Ю. Микроморфология и гистогенез яичника цыплят на ранней стадии постнатального онтогенеза / О. Ю. Царева // Сборник материалов Международной научно-практической конференции, посвященной 100-летию со дня рождения Заслуженного деятеля науки РСФСР, доктора вет. наук, профрессора Кабыша А. А. - Троицк, 2017. - С. 428-434.

15. Aitken, R. N. Observations on the fine structure of the infundibulum of the avian oviduct / R. N. Aitken, H. S. Johnston // J. Anat. - 1963. - V. 97. - № 1. - P. 87-99.

16. Chousalkar, K. K. Ultrastructural changes in the oviduct of the laying hen during the laying cycle / K. K. Chousalkar, J. R. Roberts // Cell Tissue Res. - 2008. - V. 332 (2). - P. 349-58.

17. Solomon, S. E. Studies of isthmus region of domestic fowl / S. E. Solomon // Br Poult Sci. 1975. - № 16(3). - P. 255-258.

18. Федеральная служба государственной статистики [Электронный ресуpc]. URL: http://www. gks. ru/ (дата обращения 01.11.2019). 
UDC 636.5 .03

DOI: $10.36461 / N P .2019 .52 .3 .016$

\title{
CYTOMETRIC INDICATORS OF THE EPITHELIAL LAYER OF THE HEN OVIDUCT IN THE AGE INTERVAL OF 30-120 DAYS
}

\author{
R. Yu. Khokhlov, Doctor of Biological Sciences, assistant-professor; \\ S. I. Kuznetsov, Candidate of Biological Sciences, assistant-professor
}

Federal State Budgetary Educational Institution of Higher Education «Penza State Agrarian University», Russia, t. (8412) 628-151, e-mail: roman_kh@rambler.ru

The article is devoted to the study of cytometric parameters of the epithelial layer of the mucous membrane of the oviduct of hens before the start of egg-laying, namely from 30 to 120 days of age. As a result of the analysis of the obtained cytometric indicators, it was found that the thickness of the epithelial layer of the cranial part of the oviduct progressively increases from 30 to 90 days of age. A similar trend is observed in the caudal part of the oviduct a month later, that is, from 60 days of age. Cranial epithelial cells had the largest nuclei at the age of 90 days, and caudal - at the age of 120 days. The sizes of epithelial cells in the cranial region varied from the minimum values at the age of 30 days to the maximum values at the age of 60 days. The minimum area of epithelial cells is noted in the caudal region, as well as in the cranial, at the age of 30 days. However, the maximum area of epithelial cells in the caudal region does not coincide with the cranial region, since the largest epithelial cells in the caudal region are observed at 120 days of age. The minimal ratio of nuclei to the cytoplasm in the cranial part of the oviduct was observed at 60 days of age, and in the caudal - at 90 days of age. The highest nuclear cytoplasmic ratio in the cranial part was recorded at 30 days of age, and in the caudal part - at 30 and 120 days of age.

Key words: hen, oviduct, epithelium, morphogenesis, nuclear cytoplasmic ratio

\section{References:}

1. Alexandrova, T. L. Features of blood supply to the reproductive organs of chickens of various breeds / T. L. Alexandrova, S. A. Velichkevich, N. B. Rybalova // Increasing the productivity of farm animals: scientific works of the Leningrad Agricultural Institute. - Leningrad-Pushkin, 1976.-- p. 100-103.

2. Bondarenko, E. E. The influence of geese length of rest after autumn egg production on productive qualities in the spring / E. E. Bondarenko // Ptitsevodstvo. - 1985. - V. 38. - p. 50-54.

3. Bondarenko, E. E. The histostructure of the oviduct of geese of 2 months of age / E. E. Bondarenko // Veterinary medicine. - 1998. - Vol. 74. - p. 109-114.

4. Voloshchenko, M. V. Oxidative activity of mitochondria in the protein section of the chicken oviduct, depending on age / M. V. Voloshchenko // Collection of scientific papers. V. 309. - Kharkov Agricultural Institute. - Kharkov, 1984. - p. 49-53.

5. The histofunctional state of the oviduct in chickens during shell formation / V. I. Georgievsky, K. S. Zablotskaya, E. V. Fedotov, Yu. M. Demin // Bulletin of the Timiryazev Agricultural Academy. 1988. - V. 4. - p. 145-150.

6. Gladkov, B. A. Blood-forming tissues in the ovary of chickens / B. A. Gladkov // Materials of the All-Russian Scientific and Educational-Methodical Conference on Obstetrics, Gynecology and Biotechnology of Animal Reproduction. - Voronezh, 1994. - P. 43-44.

7. Kushkina, Yu. A. Histomorphological, stereometric and histochemical characteristics of the shell section of the chicken oviduct / Yu. A. Kushkina, R. Z. Siraziev // Age-related physiology and pathology of agricultural animals: international materials of scientific conference dedicated to 90th anniversary of professor V. R. Filippov. - Ulan-Ude, 2003.-- Part 1. - p. $42-44$.

8. Rodin, E. V. Critical periods of morphogenesis of chicken ovary in postembryonic ontogenesis / E. V. Rodin, S. I. Kuznetsov // Actual problems of veterinary medicine and biology: conference proceedings. - Orenburg, 2003.-- p. 75-78.

9. Rodin, E. V. Morphology of chicken ovary follicles in prepubertal ontogenesis / E. V. Rodin, S. I. Kuznetsov // Actual aspects of ecological, comparative species, age and experimental morphology: conference proceedings. - Ulan-Ude, 2004.-- p. 43-45.

10. Stepina, O. Yu. Histogenesis, features of micromorphology and histochemistry of the surface epithelium of various compartments of the chicken oviduct in the postnatal period of ontogenesis / O. Yu. Stepina // Achievements of evolution, age and environmental morphology - practice of medicine and veterinary medicine: materials of international scientific and practical conference of morphologists. Omsk, 2001.-- p. 12-14. 
11. Strizhikova, S. V. Morphological, histochemical and ultramicroscopic characteristics of the surface epithelium of the oviduct of the duck during oviposition / S. V. Strizhikova // Actual problems of veterinary medicine, animal husbandry, commodity science, social studies and training in the Southern Urals at the turn of the century: materials of the conference. - Troitsk, 2000. - Part 1. - p. 102-104.

12. Strizhnikov, V. K. Dynamics of growth of body weight and organs of reproduction of geese in postnatal ontogenesis / V. K. Strizhnikov, A. A. Tegza // Actual problems of veterinary medicine. - Troitsk, 2002.-- p. 120-121.

13. Tsareva, O. Yu. Micromorphology and histogenesis of the shell region of the oviduct of chickens during various periods of postnatal ontogenesis and depending on the phase of the reproductive cycle / O. Yu. Tsareva // Problems of veterinary medicine, veterinary-sanitary examination, biotechnology and livestock technology at the present stage the development of the agro-industrial complex of Russia: a collection of materials of the International scientific-practical conference of the Institute of Veterinary Medicine. - Chelyabinsk, 2019.-- p. 75-81.

14. Tsareva, O. Yu. Micromorphology and histogenesis of the ovary of chickens at an early stage of postnatal ontogenesis / O. Yu. Tsareva // Collection of materials of the International scientific and practical conference dedicated to the 100th anniversary of the Honored Scientist of the RSFSR, Doctor of Veterinary sciences, professor Kabysh A. A. - Troitsk, 2017.-- p. 428-434.

15. Aitken, R. N. Observations on the fine structure of the infundibulum of the avian oviduct $/$ R. N. Aitken, H. S. Johnston // J. Anat. - 1963. - V. 97. - № 1. - P. 87-99.

16. Chousalkar, K. K. Ultrastructural changes in the oviduct of the laying hen during the laying cycle / K. K. Chousalkar, J. R. Roberts // Cell Tissue Res. - 2008. - V. 332 (2). - P. 349-58.

17. Solomon, S. E. Studies of isthmus region of domestic fowl / S. E. Solomon // Br Poult Sci. 1975. - № 16(3). - Р. 255-258.

18. Федеральная служба государственной статистики [Электронный ресуpc]. URL: http://www. gks. ru/ (дата обращения 01.11.2019). 